\title{
TEACHERS' PROFESSIONAL SKILLS AS THE COMPONENT OF THE QUALITY OF HIGHER EDUCATION AND THE ELEMENT OF STUDENTS' MOTIVATION
}

\author{
Roman Chopyk \\ Drohobych Ivan Franko State Pedagogical University, Ukraine \\ Nina Hrybok \\ Drohobych Ivan Franko State Pedagogical University, Ukraine \\ Natalya Zakalyak \\ Drohobych Ivan Franko State Pedagogical University, Ukraine \\ Mykola Lukjanchenko \\ Drohobych Ivan Franko State Pedagogical University, Ukraine
}

\begin{abstract}
The problem of studying the significance of teachers' professional skills as the component of the quality of higher education and the element of students' motivation is being analyzed in the article. The purpose of the research is study and analyzes of students' attitude towards teachers' professional skills as the component of the quality of higher education. The research has been conducted with the help of theoretical and empirical methods. Connection between the quality of higher education and teachers' professional skills has been established with the help of dialectical method. The use of comparative method allowed us to implement the raking division of students' attitude towards teachers' professional skills. The empirical base of the research consists of the results of the survey of 175 students of Drohobych Ivan Franko State Pedagogical University. The following teachers' professional skills: the ability to arouse the interest for the subject; clarity, accessibility and comprehensibility of the information layout; the ability to create a teamwork, motivate to achieve goals have been granted the highest ranking according to students' attitude towards teachers' professional skills. Such skills as objectivity and transparency of evaluation; goodwill and tactfulness; creative approach to studying; subject competence; erudition and culture of speech are highly evaluated. The following qualities: the culture of a dress code; organizational culture; the ability to act accordingly with moral, ethical and legal standards; the ability to recognize, formulate and solve problems constitute the interim position of the general ranking. Content significance and accessibility of the information which is being taught; skills of informational technologies; the ability to choose forms and methods of teaching which comply with studentoriented approach have been positioned at the lowest point of the general ranking according to the survey.
\end{abstract}

Keywords: Ukraine; ranking; students; incentive; skills; higher education. 
Chopyk et al., 2021. Teachers' Professional Skills as the Component of the Quality of Higher Education and the Element of Students' Motivation

\section{Introduction}

One of the main conditions of successful being of any modern country is good education. Education is the basis of intellectual, spiritual, physical and cultural development of any personality, his/her successful socialization, economic wellbeing, guaranty of development of society united by common values and culture and the country (Pro osvitu: Zakon Ukrainy, 2017). Modern education is characterized not only by the level of knowledge, skills and abilities but also by the quality of personal, worldview and civic development of future generation (Kharchenko, 2018).

The quality of education is the congruence of study results with the requirements established by the law, relevant educational standards and/or by the educational services agreement (Pro osvitu: Zakon Ukrainy, 2017). By quality of education, we mean the certain level of knowledge and abilities, mental, physical and moral development that was attained by the graduates of educational establishment according to the pre-arranged aims of studies and education.

Nowadays Ukraine undertakes firm steps towards the development of the system of providing of quality of education, including higher education. It allows build the trust of society to educational establishments, organs of education management and to guarantee the high level of quality of educational process. An institution, which is responsible for the observance of quality of higher education - National Agency of Higher Education Quality Guarantee (NAHEQG), has been created. The national agency, in accordance with Charter, annually prepares and publicates a report on quality of higher education in Ukraine. The reports are -sent to the Verkhovna Rada of Ukraine, the President of Ukraine, the Cabinet of Ministers of Ukraine and establishments of higher education for further discussion and proper actions (Postanova Kabinetu Ministriv Ukrainy «Pro utvorennia Natsionalnoho ahentstva iz zabezpechennia yakosti vyshchoi osvity», 2015).

The law of Ukraine "About higher education" closely correlates with the European standards and recommendations in relation to the internal and external assurances of quality of higher education. In accordance with the indicated law, higher educational establishments of Ukraine are obliged to have internal system of providing of quality of higher education and educational activity. The efficiency of this system must be estimated by National Agency of Higher Education Quality Guarantee (Sydorenko, 2016).

In Drohobych Ivan Franko State Pedagogical University the system of the internal guarantee of quality of education functions on the basis of «Statute about the system of the internal guarantee of quality of higher education in DSPU» (Polozhennia pro systemu vnutrishnoho zabezpechennia yakosti vyshchoi osvity u DDPU imeni Ivana Franka, 2015). It indicates the availability of multilevel 
control including students' control. One of ways of realization of function of controlling quality of educational activity by students is their participation in realization of internal and external measures of controlling quality of educational activity and quality of higher education, including means of monitoring.

The aim of the research is study and analyzes of students' attitude towards teachers' professional skills as the component of the quality of higher education.

\section{Theoretical Substantiation of the Problem}

The problem of teachers' professional skills has been in focus of attention of domestic and foreign specialists for quite a long time. The Motivational-valued component of inclusive skill of future teachers is studied in work by Kucheruk (Kucheruk, 2012).

The problem of study of interconnection between teachers' professional skills and quality of education has already become a traditional subject for discussion on conferences in Latvia (Augskalne \& Garjane, 2019; Bobkova, Melnychuk, Melnychuk, Melnychuk, \& Pypiak, 2020). Existence of direct connection between the level of development of teachers' professional skills and their academic respectability has been depicted (Bobkova et al., 2020). It has been also stated that the inhibition of academic respectability by academic staff can be implemented by developing motivational-valued, cognitive-operational, reflective-evaluating components of teachers' professional skills.

Works, which expose the problem of forming of motivation of students' educational-cognitive activity deserve proper attention in the context of our research. The notion of motive is the complex phenomenon, which scientists describe to be too complicated to give the unambiguous definition. Il'in determines the motive as difficult psychological formation, that induces to the conscious actions and acts, and which is the basis for these actions as well (Il'in, 2000). In his opinion, the notion of motive often designate such psychological phenomena as intention, desire, aspiration, fear etc. These phenomena represent the presence of determination in the human psyche that induces the achievement of a certain goal.

Honcharenko defines the motive as the main incentive of actions, person's acts, which are aimed at meeting the needs, and as something, that calls to action (Honcharenko, 1997, 47).

The notion of «motivation» is also the complex phenomenon and much broader than the notion of «motive». Honcharenko understands motivation as the system of motives or stimuli, factors, that determine concrete activity, person's behavior (Honcharenko, 1997, 47).

Formation of motivation is possible only when a person succeeds in connecting the aim with personal values. The more the personal values are 
connected with the result of future action, the more the inner motives nourish the energy of personal motivation. Motivation is the main driving force of any human activity and the professional one is not an exception. Motivation is one of the leading factors of successful study of a young person, which includes her/his professional growth. Development of positive educational motivation of students is one of the conditions of personal development and effective professional training (Bondar, 2017).

Description of motives of educational activity requires special attention as they influence the quality of professional training. Here are some of them: cognitive, professional, motives of creative achievement, broad social motives, motives of the personal prestige, motive of self-realization, financial motives.

Bondar states (Bondar, 2017, p. 13) that professional-cognitive need should be the leading need in educational activity of a student.

As well as any other type of motivation, educational motivation is determined by the series of specific for this activity factors: by the educational system, educational establishment of education, organization of educationaleducator process, subject features of the one who studies and the one who teaches, by the characteristics of educational subjects (Pidhorodetska, 2007).

Thus, the motivational constituent of educational activity embraces cognitive necessities, motives and senses of studies. As Cherniak marks (Cherniak, 2013), students should feel the rising of a need in self-perfection, self-realization and self-expression during classes. Collaboration between a teacher and students as well as between students only plays a significant role in forming of this need. This collaboration is implemented by means of dialogue in an educational process.

The results of the theoretical study give us the right to claim that the question of students' attitude towards teachers' professional skills as the factor of motivation to educational activity has been left behind the attention of scientists.

\section{Methods of the Research}

The research has been conducted with the help of theoretical and empirical methods. Connection between the quality of higher education and teachers' professional skills has been established with the help of dialectical method. The use of comparative method allowed us to implement the raking division of students' attitude towards teachers' professional skills.

The empirical base of the research consists of the results of the survey of Drohobych Ivan Franko State Pedagogical University students. The survey has been conducted in February 2020 within the framework of internal control of the quality of educational process in the educational-scientific institute of physical culture and health of Drohobych Ivan Franko State Pedagogical University. The students of the $2^{\text {nd }}-4^{\text {th }}$ years of the first (bachelor) level of higher education 
participated in a questionnaire. The questionnaire includes 175 students: 98 applicant of 014 «Secondary education (Physical culture)» specialty and 77 applicants of 227 «Physical therapy and ergotherapy» specialty. The aim of the survey consisted in the study of students' attitude to professional skills of teacher as component quality of higher education and factor of motivation to educational activity. The survey was conducted by writing anonymous questionnaire. The collected results were analyzed by means of methods of mathematical statistics.

\section{Results of the Research}

We have already studied values and motives of health of students' conservation activities (Hrybok, Chopyk, \& Zakaliak, 2017). In this research it was important to create motivation to study of applicants of higher education in the university.

As Mykhailychenko \& Polianska state, the research of the problem of motivation forming of educational-cognitive activity in the establishment of higher education gives an opportunity for many aspects of internal life of student to become the object of study: his/her interests, values and beliefs, motives of activity, talents, knowledge, abilities, and skills. These aspects will be the part of his/her professional orientation in the future.

As the results of the survey show (see Figure 1), majority of students have the proper motivation - to acquire professional knowledge and skills and to become a highly skilled specialist that is in accordance with a cognitive need. This kind of motivation prevails in 52\% of respondents. However, the level of motivation of students - majoring in 227 «Physical therapy, ergotherapy» is higher, than among their colleagues - majoring in 014 «Secondary education (Physical culture)», and makes $60,6 \%$ versus $44,4 \%$ accordingly.

To find a good job in the future can be counted as another powerful motive of students to studying. It induces $36,2 \%$ of students to get higher education (39,4\% of students with speciality 227 «Physical therapy, ergotherapy» and $33,3 \%$ of students - 014 «Secondary education (the Physical culture)». It is important to notice that among the applicants of higher education there is certain amount of students, who do not have clear motivation, and study in the university only to get higher education. They consist $14,5 \%$ of students $(2,3 \%$ of students with specialities 227 «Physical therapy, ergotherapy» and 19,4\% with speciality 014 «Secondary education (Physical culture)» accordingly). Prestige of having higher education degree is the main motive for $7,2 \%$ of students $(6,2 \%$ of students with speciality 227 «Physical therapy, ergotherapy» and 8,3\% of students with speciality 014 «Secondary education (Physical culture)»).

Thus, the results of questionnaire indicate that the majority of students have the proper level of motivation for acquiring higher education in higher educational 
Chopyk et al., 2021. Teachers' Professional Skills as the Component of the Quality of Higher Education and the Element of Students' Motivation

establishment. However, there is small percent of students that study simply in order to have higher education. Obviously, that for the representatives of this category the absence of the proper motivation in studies can be pre-condition of their slow progress. It corresponds with the studies of Cherniak \& Hyliun. (Cherniak, 2013; Hyliun, 2012).

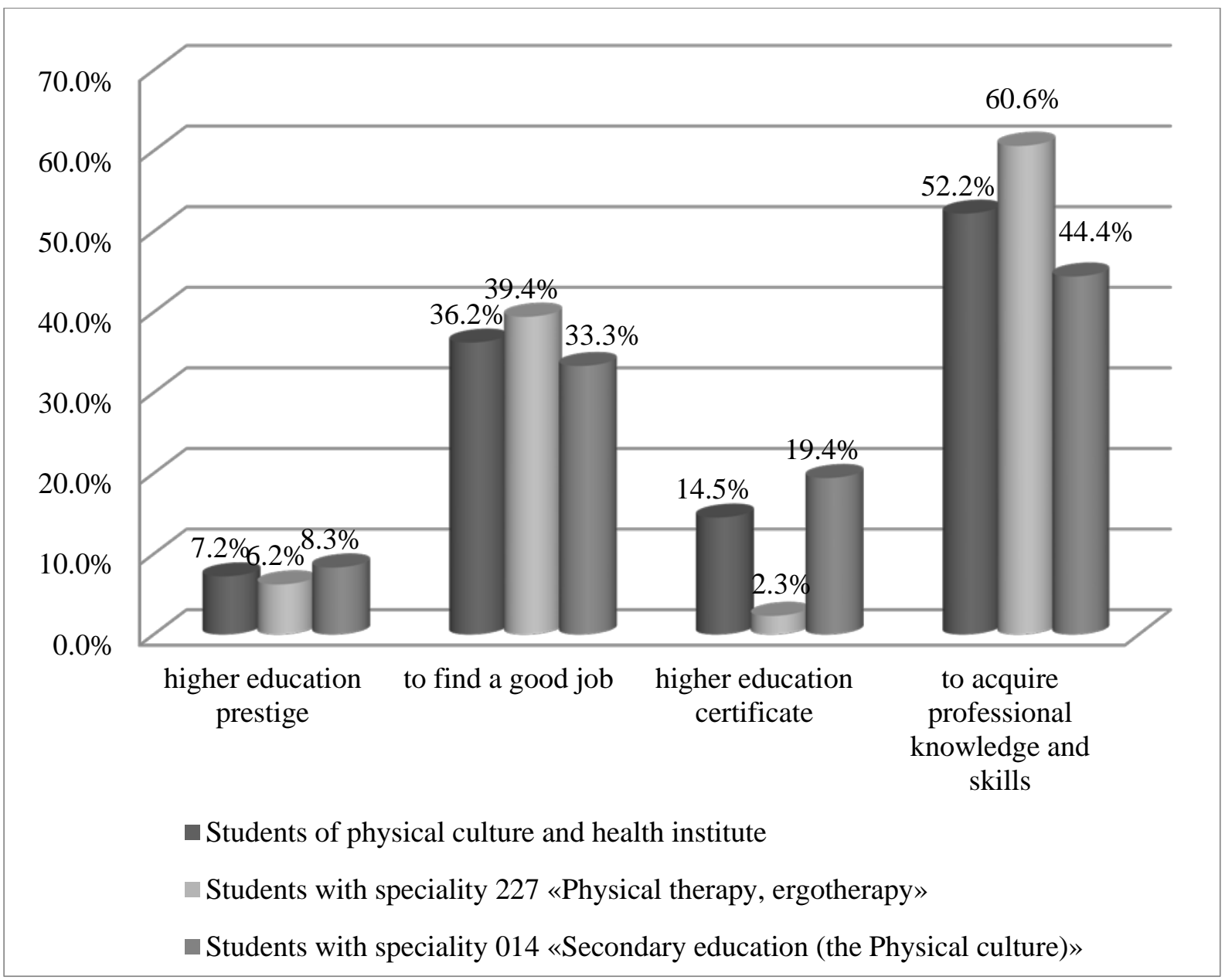

Figure 1 Motivation of Students of the Institute to Higher Education

The important constituent of effective educational process is a highly skilled teacher that has necessary skills. A professional competence of a teacher, especially pedagogical mastery, is the substantial factor of increase of motivation to studying and to interest in a profession. Therefore, we tried to figure out with the help of questioning, which qualities of teacher are valued most highly by a student nowadays. Such information is useful for administration of institute in making administrative and personnel decisions addressed to upgrade educational process. 
The results of questioning of students showed that generally according to the level of significance for students the represented skills can be divided into several conditional groups. The following teacher's skills appeared to be the most significant for the students: ability to arouse interest to discipline; clearness, accessibility and intelligibility of material presentation; ability to create a team and motivate to achievement of aims. The indicated skills belong to one conditional group, as their distribution has a clear maximum and similar dynamics of decrease. The majority of the questioned students consider that these teacher's skills are determinative for providing the proper quality of educational process.

Obviously, in our opinion, the first place in the consolidated rating of teacher's skills occupied ability to arouse interest in discipline (see Figure 2). Teacher's ability to clearly and intelligibly present material is also highly valued by modern students and it occupies the second place in the consolidated student rating. Teacher's ability to create a team and to motivate to achieve aims concedes a bit prior to skills however these are also significant.

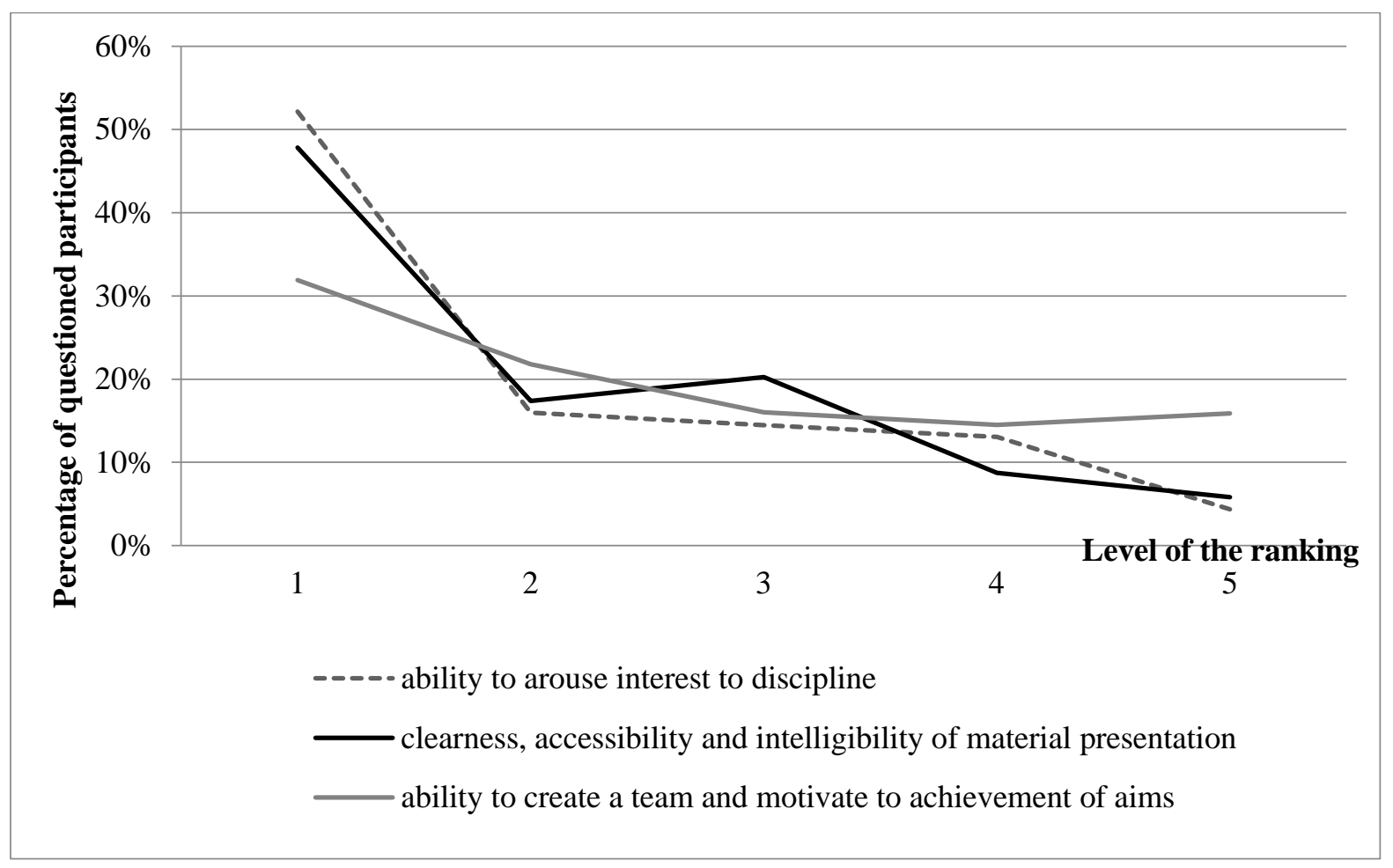

Figure 2 Division of Teacher's Skills with the Highest Ranking

The second conditional group of the student rating consists of the following teacher's skills: objectivity and evaluation transparency; goodwill and tactfulness; creative approach to teaching; subject competence; erudition and culture of speech. Indicated skills are attributed to the separate conditional group due to clearly expressed maximum and the similar dynamics of decrease (see Figure 3). 


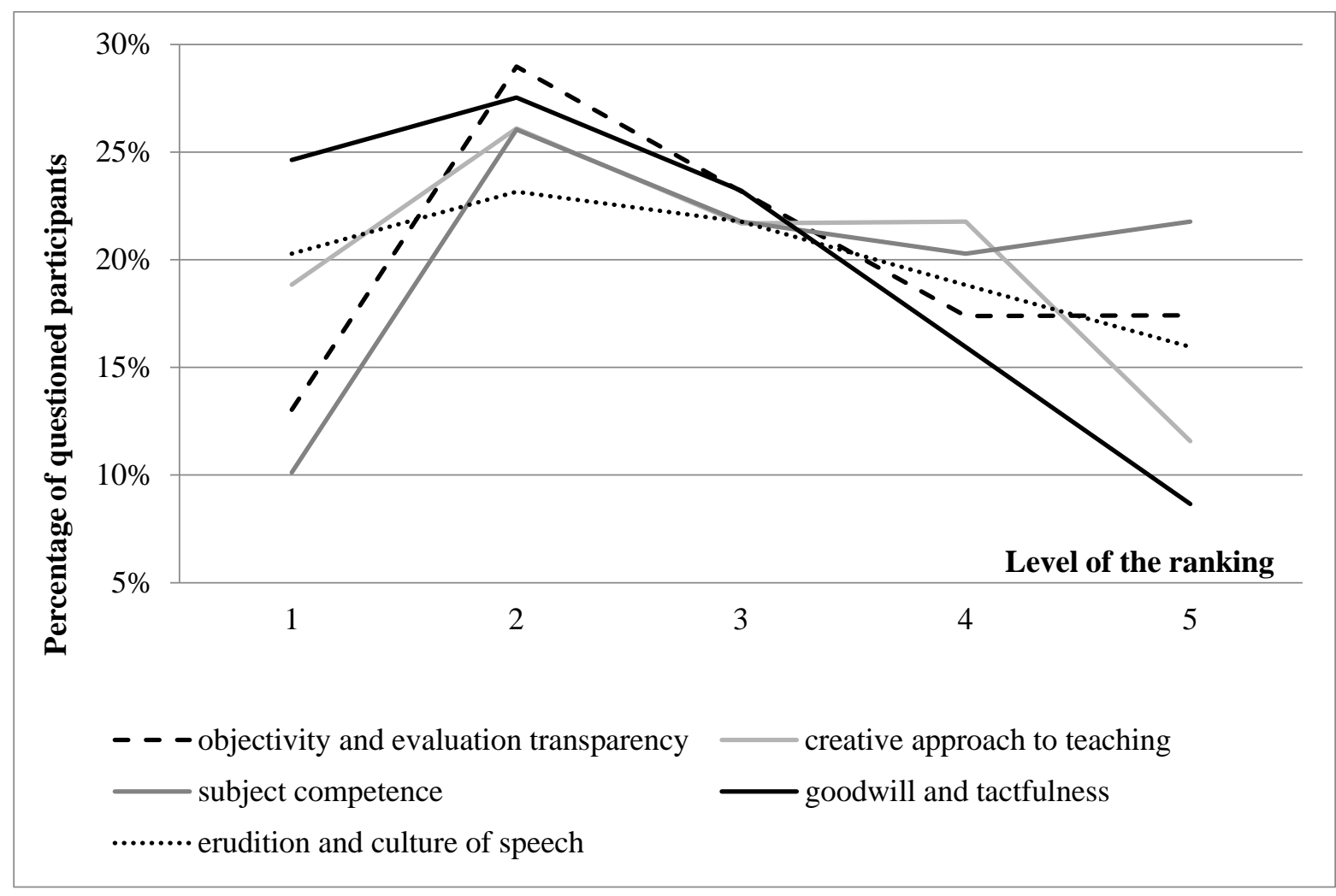

Figure 3 Ranking Division of Teacher's Skills of the Second Group

One of key skills, that constitute this group, are goodwill and tactfulness of teachers. The presence of such an approach fully meets principles of humanism and - puts emphasis on the importance of the construction of educational process, when a student is its subject. Students also give special value to objectivity and evaluation transparency that, in our opinion, have a key value for forming of academic respectability and quality of higher education in general. Without doubt, the knowledge of material as teacher's skill is essential for ensuring the quality of higher education. Such skills as creative approach to teaching, erudition and culture of speech are positioned a bit lower in the student's rating.

The third conditional group of the general rating consists of the qualities, which students consider not to be the last, but at the same time, they are far from being the first (see Figure 4). By the results of survey, the third group teacher's skills are the culture of appearance; organizational culture; ability to act accordingly with moral, ethical and legal standards; the ability to recognize, formulate and solve the problem. 


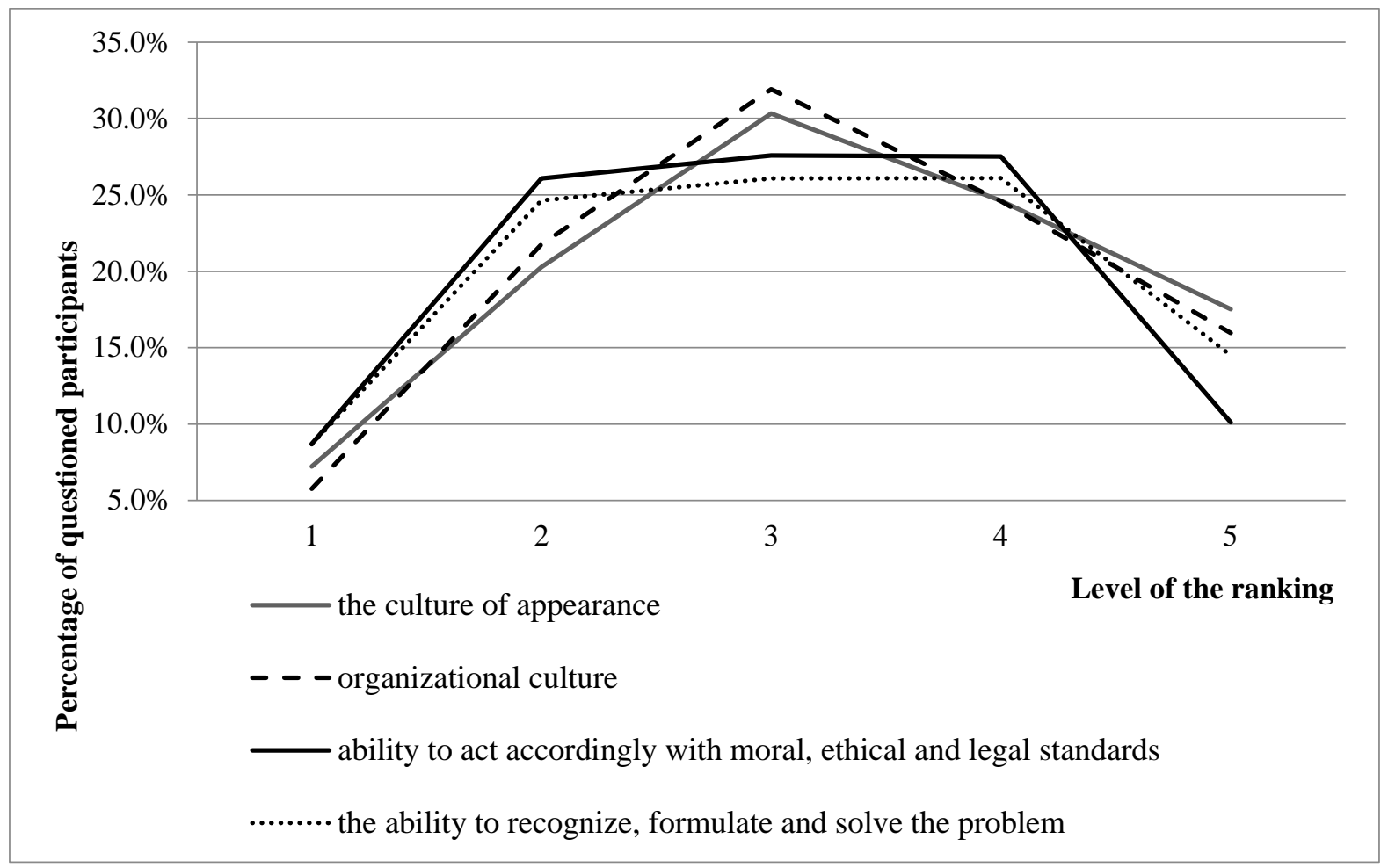

Figure 4 Ranking Division of Teacher's Skills of the Third Group

The qualities, that students evaluate the least, constitute the last groups of general rating (see Figure 5). The skill of «content significance and study material accessibility» can still be referred to the conditioned group with the priority №4. While two other - «skills of informational technologies» and «the ability to choose forms and methods of teaching, which comply with student-oriented approach» are firmly positioned at the lowest level of the ranking and can form the separate fifth group.

«The ability to choose forms and methods of teaching, which comply with student-oriented approach» received the poor evaluation of significance for students and the same position in ranking accordingly (see Figure 5). It's important to note that the students - majoring in 014 «Secondary education (Physical culture)» value this skill less than students - majoring in 227 «Physical therapy, ergotherapy». We believe that this depends on the fact that students majoring in 014 «Secondary education (Physical culture)» have more hardened temper as sportsmen.

As the results of the survey show, the teacher's skill of informational technologies was positioned at the lowest level of the students' ranking (see Figure 5). It might be due to the fact that at the moment the survey was conducted the use of informational technologies in the educational process, including the field of physical culture, had not been yet so important and spread so broadly. 
Chopyk et al., 2021. Teachers' Professional Skills as the Component of the Quality of Higher Education and the Element of Students' Motivation

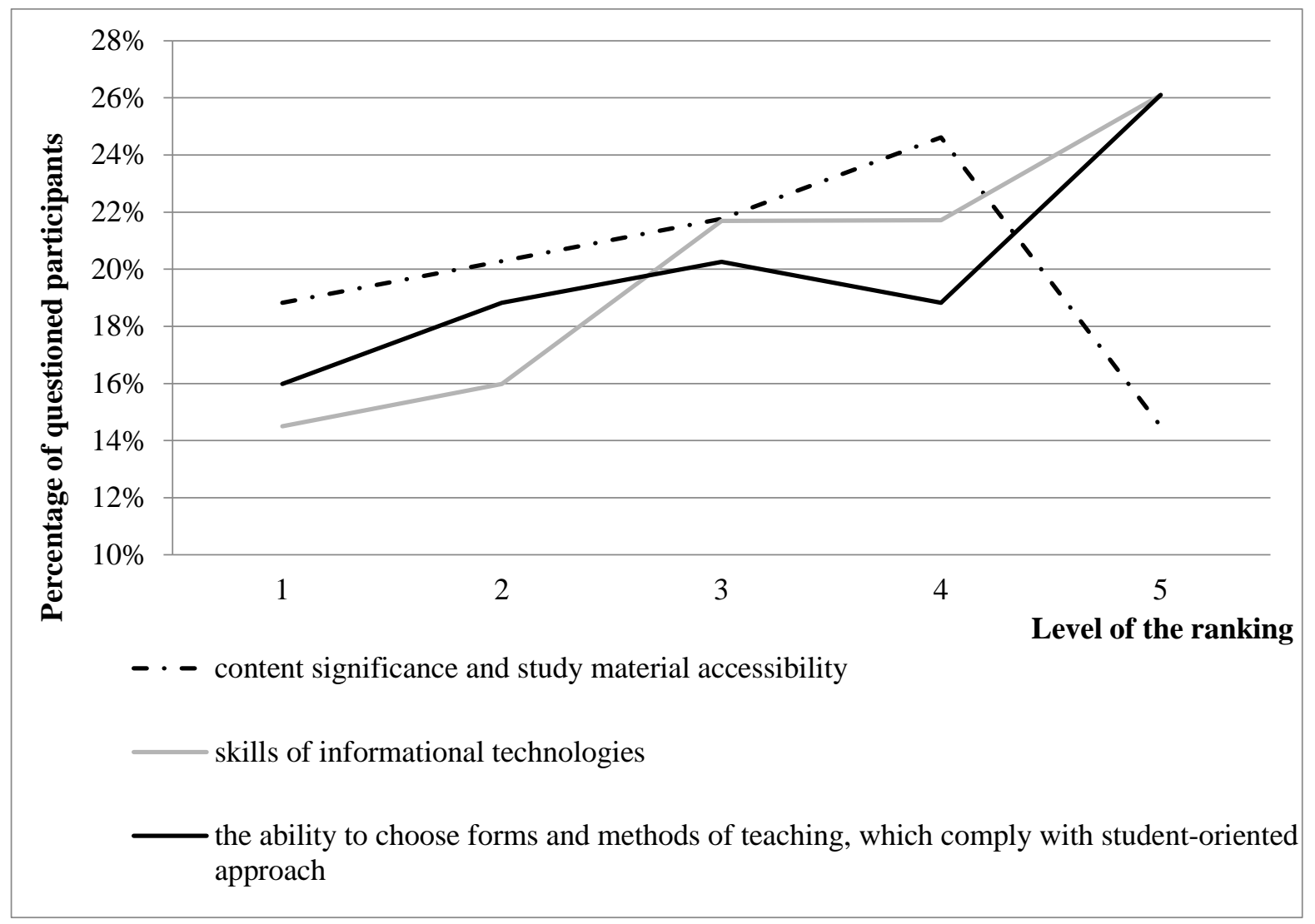

Figure 5 Division of Teacher's Skills with the Lowest Ranking

\section{Conclusions}

During the research, we analyzed the collected data about students' attitude towards teachers' professional skills as the component of the quality of higher education. We confirmed the correlation between motivation of applicants for higher education to studying and teacher's professional skills.

We conducted the ranking division of students' attitude towards teacher's professional skills. The common features of the dynamics of ranking division of teacher's skills had been displayed, that helped us to divide them into several conditioned groups according to the level of their significance to students. The following teachers' professional skills: the ability to arouse the interest for the subject; clarity, accessibility and comprehensibility of the information layout; the ability to create a team, motivate to achieve goals have been granted the highest ranking according to students' attitude towards teachers' professional skills. Such skills as objectivity and transparency of evaluation; goodwill and tactfulness; creative approach to teaching; subject competence; erudition and culture of speech are highly evaluated by students. The following qualities: the culture of appearance; organizational culture; the ability to act accordingly with moral, 
ethical and legal standards; the ability to recognize, formulate and solve problems constitute the interim position of the general ranking. Content significance and accessibility of the information, which is being taught; skills of informational technologies; the ability to choose forms and methods of teaching, which comply with student-oriented approach, have been positioned at the lowest point of the general ranking according to the survey.

Thus, on the basis of conveyed analyzes we confirmed the importance of teacher's professional skills for ensuring the quality of higher education and for forming the students' motivation for studying.

\section{References}

Augskalne, I., \& Garjane, B. (2019). Formation of teachers' competences in further education. Society. Integration. Education, Proceedings of the International Scientific Conference. DOI: http://dx.doi.org/10.17770/sie2019vol5.3885

Bobkova, A., Melnychuk, O., Melnychuk, O., Melnychuk, M., Pypiak, M. (2020). Development of Professional Competency of Teachers as the Maintenance of Academic Goodwill. Society. Integration. Education, Proceedings of the International Scientific Conference, (1), 56-66. DOI: http://dx.doi.org/10.17770/sie2020vol1.4835

Bondar, L. (2017). Osoblyvosti motyvatsii navchalnoi diialnosti studentiv - maibutnikh praktychnykh psykholohiv. Visnyk Natsionalnoho aviatsiinoho universytetu. Seriia: Pedahohika. Psykholohiia. (10). 20-23. DOI: 10.18372/2411-264X.10.12459

Cherniak, N. (2013). Formuvannia motyvatsii studentiv do navchannia u VNZ. Problemy inzhenerno-pedahohichnoi osvity, (38-39), 388-393. Retrieved from: http://nbuv.gov.ua/UJRN/Pipo_2013_38-39_63

Honcharenko, S. (1997). Ukrainskyi pedahohichnyi slovnyk. Kyiv: Lybid.

Hrybok, N., Chopyk, R., Zakaliak, N. (2017). Monitorynh sformovanosti kultury zdorovia studentiv pedahohichnoho universytetu. Human health: realities and prospects. Monographic series. (2), "Health and Environment”. Drohobych: Posvit, 348-359.

Hyliun, O. (2012). Osvitni motyvatsii studentskoi molodi. Hrani: naukovo-teoretychnyi i hromadsko-politychnyi almanakh, 1 (81), 102-104.

Il'in, E. (2000). Motivaciya i motivy. Sankt-Peterburg: Piter.

Kharchenko, N. (2018). Stratehiia yakosti yak osnova osvitnoi polityky. Dyrektor shkoly. Shkilnyi svit, (2). Retrieved from http://www.osvitaua.com/2018/04/63688/

Kucheruk, O. (2012). Harakteristika motivacijno-cinnisnogo komponentu inkljuzivnoï kompetentnosti majbutn'ogo vchitelja. Naukovij chasopis NPU imeni M. P. Dragomanova. Serija 16, Tvorcha osobistist' uchitelja: problemi teoriï i praktiki, 18, 20-23.

Mykhailychenko, V., \& Polianska, V. (2011). Rol motyvatsii navchalno-piznavalnoi diialnosti u formuvanni profesiinoi spriamovanosti studentiv. Pedahohika formuvannia tvorchoi osobystosti u vyshchii i zahalnoosvitnii shkolakh, 17 (70), 320-327.

Pidhorodetska, V. (2007). Problema formuvannia motyvatsii navchalnoi diialnosti studentiv. Nauchnyj progress na rubezhe tysyacheletij: materialy II mezhdunarodnoj nauchnoprakticheskoj konferencii, (9), 23-26. Retrieved from: http://www.rusnauka.com/ 11._NPRT_2007/Pedagogica/22405.doc.htm

Polozhennia pro systemu vnutrishnoho zabezpechennia yakosti vyshchoi osvity u Drohobytskomu derzhavnomu pedahohichnomu universyteti imeni Ivana Franka. (2015). 
Chopyk et al., 2021. Teachers' Professional Skills as the Component of the Quality of Higher Education and the Element of Students' Motivation

vid 28.12.2015 r. № 636. Retrieved from: http://dspu.edu.ua/wp-content/uploads/ 2016/11/polozhennya-pro-systemu-vnutrishnogo-zabezpechennya-yakosti-vyshhoyiosvity-u-ddpu-im.-i.franka.pdf

Postanova Kabinetu Ministriv Ukrainy. (2015). vid 15 kvitnia 2015 r. № 244 «Pro utvorennia Natsionalnoho ahentstva iz zabezpechennia yakosti vyshchoi osvity». Retrieved from https://zakon.rada.gov.ua/laws/show/244-2015-\%D0\%BF/ed20190828\#Text

Pro osvitu: Zakon Ukrainy. (2017). Prijnjatij 5 veresnja 2017 r. 2145-VIII. Retrieved from https://zakon.rada.gov.ua/laws/show/2145-19\#Text

Sydorenko, N. (2016). Vnutrishnie zabezpechennia yakosti vyshchoi osvity v Ukraini yak suspilno-osvitnii priorytet. Derzhavne upravlinnia ta mistseve samovriaduvannia, (4). 81-86. Retrieved from: http://nbuv.gov.ua/UJRN/dums_2016_4_14

Yakist osvity. (2020). Retrieved from https://mon.gov.ua/ua/tag/yakist-osviti 